ЧИСТЯКОВА О.О.

\title{
КОДЕКС ДОБРОЧЕСНОСТІ ЯК ЕЛЕМЕНТ МЕХАНІЗМУ ПОБУДОВИ НАЛЕЖНОГО УРЯДУВАННЯ В СЕКТОРІ БЕЗПЕКИ УКРАЇНИ
}

У статті розглянуто особливості застосування Кодексу доброчесності у діяльності державних правоохоронних органів, зокрема в органах внутрішніх справ України, прокуратурі України та інших. Досліджено, як саме застосовуються критерії доброчесності у поведінці співробітників прокуратури та Служби безпеки України, спрямовані на боротьбу з корупцією. Розбудова доброчесності є важливим елементом стратегії урядування, покладеної в основу реформування сфери безпеки. Реформування сфери безпеки - це процес політичних і технічних реформ, проведений із метою покращення функціонування урядування в кожному 3 державних органів.

Однією з провідних організацій у справі розбудови доброчесності є НАТО з іiі програмою створення можливостей і практичних інструментів, які допомагають країнам-членам зміцнити доброчесність, прозорість і підзвітність і знизити ризик корупції в секторі оборони та безпеки. Програми НАТО з розбудови доброчесності враховуються під час реформування сфери безпеки в Україні. Нині реформування сфери безпеки має доповнювати загальнодержавний рух на національному рівні до ефективного врядування та боротьби з корупцією.

Розглянуто низку заходів та інструментів розбудови доброчесності у сфері безпеки. Виокремлено успішні програми розбудови доброчесності, які мають бути якомога повнішими, в той же час залишатися реалістичними, з досяжними цілями, узгоджуватися з конкретною ситуацією. Підкреслено важливість застосування досвіду належності урядування країн-членів НАТО у процесі реформування сектору безпеки країни.

Розробка механізмів розбудови доброчесності - це широкий процес, який охоплює багато діячів та органів в усьому світі. На національному рівні цим займається уряд та залучаються інші зацікавлені сторони: парламент, міністри, комітети. Програма прописується в стратегії національної безпеки. Контроль за виконанням і ії̈ додержанням військовими та цивільними співробітниками покладається на парламент, громадське суспільство та інші органи, уповноважені здійснювати нагляд. Національне законодавство забезпечує базу для цього процесу. На міжнародному рівні міжнародні організації забезпечують навчання, інструктаж і зовнішній нагляд. Інші держави діляться передовим досвідом і подають приклади, формалізують міжнародні правові стандарти.

Ключові слова: доброчесність, корупџія, державні органи, прокуратура, правоохоронні органи.

In the article the peculiarities of application of the Code of integrity in the activities of state law enforcement agencies, in particular in bodies of internal Affairs of Ukraine, Prosecutor of Ukraine and others. Studied how it applied criteria of integrity in the behavior of employees of bodies of Prosecutor's office and the security Service of Ukraine which are directed on fight against corruption. The development of virtue is an important element in the strategies of good governance, underlying the reform of the security sector.

And security-sector reform is a process of political and technical reforms to improve the operation of the control in each of the state agencies. One of the leading organizations in the development of virtue, is NATO, with its program of creating opportunities

(C) ЧИСТЯКОВА О.О. - студент (Національний юридичний університет імені Ярослава Му- 
and practical tools to help member countries strengthen integrity, transparency and accountability and reducing corruption risk in defence and security. NATO program for development of integrity are considered in the context of the wider reform of the security sector in Ukraine.

Today, the reform of the security sector should complement national movement at the national level to good governance and anti-corruption. Considered a number of measures and tools for the development of integrity in the security sphere. Highlighted a successful programme for the development of virtue, which should be as full as possible, at the same time remaining realistic, with achievable goals, consistent with the specific situation. Paceline in the article the importance of using the experience belonging to the government of countries-members of NATO in the reform of the security sector of our country. Development of mechanisms for the development of virtue is a broad process that encompasses many leaders and authorities around the world. At the national level, this deals with the government and involve other stakeholders such as Parliament, Ministers, committees and the like.

The program prescribed in the national security strategy. The monitoring of implementation and compliance with military and civilian employees, is vested in the Parliament, civil society and other bodies authorized to implement supervision. National legislation provides the framework for this process. At the international level, international organizations provide training, coaching and external supervision. Other States sharing best practices, and provides examples. Finally, the process formalizes the international legal standards.

Key words: integrity, corruption, public authorities, prosecutors, law enforcement agencies.

Вступ. Корупція є суттєвою перешкодою для розвитку, безпеки та стабільності сучасних суспільств. Вона знижує довіру до державних установ і підриває боєздатність Збройних сил, а у сфері безпеки взагалі покладає важкий тягар на життя суспільства. Вона відволікає кошти держбюджету, не даючи вкладати їх в освіту, охорону здоров'я, інновації та розвиток. Саме тому важливим $є$ пошук шляхів позбутися цього, де варіантом покращення ситуації $є$ запровадження Кодексів доброчесності в діяльності сектору безпеки.

Питання про застосування кодексів доброчесності як елемента побудови і запровадження доброчесної поведінки у секторі безпеки та оборони є неоднозначним і новітнім, тому серед науковців існує багато різних думок із цього приводу. Зокрема, дослідженням цієї теми займалися О. Шинальський, О. Мартиненко, Є. Захаров, Д. Марчак, Б. Малишев та інші.

Постановка завдання. Мета статті полягає у дослідженні впливу кодексу доброчесності, визначенні елементів доброчесної поведінки стосовно формування та діяльності відповідних правоохоронних органів, з'ясуванні особливостей застосування конкретною людиною доброчесності під час виконання своїх повноважень.

Результати дослідження. Перший крок до розбудови доброчесності - виявити та оцінити ризики корупції і розробити план (стратегію) їх подолання. Урядам і фахівцям із безпеки доступні такі інструменти оцінки та планування:

- повна правова база. Важливим елементом розбудови доброчесності є належна нормативно-правова база на додачу до кодексів поведінки та настанов із етики;

- належне бюджетне планування. Багато уваги слід приділяти системі бюджетного планування. Вона має відповідати загальній стратегії національної безпеки в середньо- або довгостроковому плані;

- навчання та освіта. Освіта дуже важлива на всіх рівнях ієрархії сфери безпеки. Тому потрібна ретельна увага до навчання військового та цивільного персоналу сфери безпеки питанням розбудови доброчесності. Існує низка програм і курсів розбудови доброчесності, розроблених для військового та цивільного персоналу HATO, DCAF, CIDS та інших військових організацій і служб;

- контроль і нагляд. Щоб гарантувати успіх довгострокових зусиль із розбудови доброчесності, необхідно створити систему нагляду. Вона може включати механізми внутрішнього та зовнішнього нагляду, до яких входять інспектори, комітети з нагляду, аудитори та омбудсмен. Важлива роль у цьому процесі належить депутатам парламенту та уряду. Громадянське суспільство та ЗМІ повинні мати доступ до інформації і право контролювати сектор безпеки, щоб створити дієздатну систему запобіжників і противаг, яка дозволяє уникнути корупції [1]. 
Розбудова доброчесності - широкий процес, який охоплює багато сторін. На національному рівні програму розбудови доброчесності розробляє уряд за допомогою інших зацікавлених сторін (парламент, міністри, комітети тощо) і прописує ії в Національній стратегії (Стратегії національної безпеки). Програму виконує військовий і цивільний персонал під наглядом парламенту, громадянського суспільства та інших органів нагляду. Національне законодавство забезпечує базу для цього процесу. На міжнародному рівні міжнародні організації забезпечують навчання, інструктаж і зовнішній нагляд. Інші держави діляться передовим досвідом і подають приклади. Загалом же процес формалізують міжнародні правові стандарти.

Попри певні позитивні зміни у законодавстві, спрямовані на забезпечення прозорості та доброчесності в роботі правоохоронних органів, останні на практиці залишаються досить слабкими інститутами. Значну роль у цьому відіграють і положення законодавства, яке регламентує їх діяльність. Хоча загальні обсяги фінансування правоохоронних органів в останні роки збільшились, погіршення економічної ситуації у державі негативно вплинуло на спроможність правоохоронних органів здійснювати ефективну діяльність. Випадки недоброчесної поведінки правоохоронців, за якими не настає правових наслідків, знижують рівень громадської довіри до прокурорів, органів внутрішніх справ і державних органів загалом.

В Україні функціонує розгалужена система правоохоронних органів, основними з яких $\epsilon$ органи внутрішніх справ, прокуратура, Національна гвардія України та Служба безпеки України (СБУ), яка (крім розвідувальної діяльності) також уповноважена виявляти і розслідувати окремі види злочинів. Слідство в окремих категоріях кримінальних справ провадиться також податковою міліцією, хоча більшість таких справ відповідно до нового Кримінального процесуального кодексу України розслідують органи внутрішніх справ. Створені в структурі правоохоронних органів спеціалізовані підрозділи здійснюють протидію певним категоріям злочинів, наприклад організованій злочинності та корупції.

Спеціалізація прокурорів прив'язана до стадій кримінального процесу та функцій органів прокуратури. При цьому відсутня спеціалізація прокурорів за окремими категоріями справ, наприклад злочинами, пов'язаними з корупцією. Провадження у справах про «корупційні» злочини засноване на принципі процесуальної спеціалізації: слідчі органів прокуратури провадять досудове слідство, прокурори - здійснюють нагляд за дотриманням законів органами досудового слідства, прокурори підтримують державне обвинувачення у судах. Окремо іншими прокурорами здійснюється нагляд за дотриманням законів органами, які проводять оперативно-розшукову діяльність, зокрема у справах про корупцію.

Прокурор здійснює свої повноваження у кримінальному процесі незалежно від будь-яких органів і посадових осіб відповідно до вимог Кримінального процесуального кодексу [3]. Згідно із Законом «Про прокуратуру» прокуратура становить єдину централізовану та ієрархічну систему, яку очолює Генеральний прокурор України. Система базується на принципі підпорядкування нижчих прокурорів вищим [3].

Призначення (та повторне призначення) Генерального прокурора Президентом і парламентом, а також можливість висловлення йому недовіри політичним органом обмежує його незалежність від політичних втручань. Закон не передбачає врахування професійних якостей кандидатів на призначення прокурорами при вирішенні питань, пов'язаних з їх призначенням. Регулювання відповідних питань (у тому числі пов'язаних зі звільненням прокурорів) здійснюється Генеральним прокурором і не базується на прозорих та об'єктивних критеріях [4].

В аналогічному порядку регулюється призначення, проходження і припинення служби в органах внутрішніх справ і СБУ. Незалежність прокурорів у кримінальному процесі законодавство належним чином не забезпечує, оскільки прокурори вищого рівня мають право переглядати / скасовувати рішення прокурорів нижчого рівня та слідчих, прийнятих у кримінальному процесі, а також змінювати, доповнювати та відмовлятися підтримувати апеляційні та касаційні скарги, внесені прокурорами [3].

У Національній гвардії України Кодекс етичної поведінки є узагальненням стандартів професійної поведінки військовослужбовців і службовців Головного управління Національної гвардії України, територіальних управлінь, вищих військових навчальних закладів, територіальних управлінь, військових частин, навчальних військових частин (центрів) Національної гвардії України [6].

Кожен військовослужбовець зобов'язаний дотримуватися загальних правил етичної поведінки. які закріплюють основні принципи і моральні норми, якими повинні керуватися військовослужбовці при виконання своїх службових обов'язків. Завдяки цим принципам і нормам 
забезпечується доброчесна, неупереджена та ефективна діяльність посадових осіб. У кодексі визначальним $є$ принцип доброчесної поведінки військових осіб, тобто чесне і віддане служіння українському народові, непорушне дотримання Конституції України та законів України. Їх діяльність спрямована на забезпечення національних інтересів України під час виконання завдань і функцій держави, сприяння реалізації прав та законних інтересів людини і громадянина, підтримання позитивного іміджу держави та Національної гвардії України.

Виділяють такі основні принципи доброчесної поведінки військової (цивільної) посадової особи при виконанні службових обов'язків:

- пріоритет службових інтересів; неупередженість;

- компетентність і сумлінність;

- прозорість;

- лояльність;

- політична нейтральність;

- нерозголошення службової інформації (конфіденційність);

- утримання від виконання незаконних наказів (розпоряджень);

- корпоративність [6].

У Кодексі етичної поведінки військових посадових осіб та інших осіб, уповноважених на виконання функцій держави, у Національній гвардії України закріплюється категорія перевірки доброчесності. Тобто, кожна військова (цивільна) посадова особа усвідомлює та сприймає право суспільства на перевірку непідкупності, чесності і відповідальності своїх громадян, які виконують військовий обов'язок або працюють у Національній гвардії України. Вона повинна своєчасно та в повному обсязі виконувати вимоги законодавства щодо подання декларації особи, уповноваженої на виконання функцій держави або місцевого самоврядування, а також сприяти в здійсненні фінансового контролю щодо встановлення відповідності рівня його життя та членів його сім'ї одержаним ними доходам, проведенні повної перевірки достовірності задекларованих відомостей, точності оцінки задекларованих активів, перевірці на наявність конфлікту інтересів та ознак незаконного збагачення [6].

Відповідно до Закону України від 21.06.2018 «Про національну безпеку України» сектор безпеки підлягає обов'язковому цивільному контролю з боку Президента України, Верховної Ради України, Ради національної безпеки і оборони України, Кабінету Міністрів України, а також органів виконавчої влади та органва місцевого самоврядування, судового контролю, громадського контролю.

Цивільний контроль базується на принципах верховенства права, законності, підзвітності, прозорості, ефективності та результативності. Прозорість у свою чергу передбачає повне розкриття фінансової інформації щодо функціонування сектору безпеки та оборони з метою забезпечення ефективного використання фінансових ресурсів з урахуванням вимог Закону України «Про державну таємницю» [7].

Служба безпека Україна серйозно підходить до розбудови доброчесності, щорічно проводить навчальні тренінги для забезпечення прозорості та зменшення корупційних ризиків серед співробітників української спецслужби. За мету ставиться вдосконалення знань із питань виявлення та встановлення причин та умов виникнення корупційних ризиків, врегулювання конфлікту інтересів та дотримання моральних і етичних норм, доброчесності та порядності.

Вагомим внеском реалізації програми стало розроблення з використанням міжнародного досвіду виховання доброчесності та запобігання корупції Кодексу доброчесності співробітника Служби безпеки України. Він грунтується на загальнолюдських і професійних етичних цінностях, засадах громадського і службового обов'язку, принципах чесного і відданого служіння українському народові, неухильного виконання міжнародних зобов'язань, взятих на себе Україною, непорушного дотримання Конституції України та Законів України, виконання зобов'язань, урочисто взятих від час складання Військової присяги або Присяги державного службовця [8, с. 9].

Норми кодексу є загальними та обов'язковими у дотриманні його положень, закріплюють основні вимоги до доброчесної поведінки військовослужбовців, державних службовців та інших працівників, які проходять військову та державну службу в органах Служби безпеки України.

Кодекс закликає співробітників під час виконання службових, військових обов'язків та у позаслужбовий час дбати про свою професійну репутацію, неухильно дотримуватися конституційних принципів верховенства права та законності, усвідомлювати, що проходження служби (виконання роботи) в Службі безпеки України не сумісне з корумпованістю і хабарництвом, зловживанням службовим становищем, перевищенням службових повноважень, порушенням уста- 
новлених стандартів доброчесної поведінки. Співробітник повинен уникати особистих зв'язків, взаємовідносин, що можуть вплинути на неупередженість і об'єктивність при виконанні професійних обов'язків, скомпрометувати почесне звання співробітника спецслужби, не допускати дій, висловлювань і поведінки, які можуть викликати негативний громадський резонанс, зашкодити його репутації та авторитету Служби безпеки України $[8$, с. 10].

Висновки. Доброчесність означає чесне й повне виконання своїх обов'язків. Процес можна вважати доброчесним, якщо він працює як слід і вписується в загальну систему, частиною якої він є. Організація доброчесна, якщо ії діяльність підзвітна і компетентна, без витрат ресурсів на нечесні особисті потреби. Людина доброчесна, якщо вона робить свою справу компетентно, чесно і повністю. Доброчесність зазвичай оцінюють за допомогою перевірок і досліджень.

\section{Список використаних джерел:}

1. Демократичне урядування у секторі безпеки. Боротьба з Корупцією та Сектор Безпеки. URL: ukrainesecuritysector.com/uk/topic/боротьба-з-кору...удова-доброчесності/. граф 33.

2. Висновок Венеціанської Комісії щодо проекту Закону «Про прокуратуру», 2012, пара-

3. Кримінальний процесуальний кодекс України від 13.04.2012 № 4651-УІ // Вiдомості Верховної Ради України. 2013, № 9-10, 11-12, 13.

4. Малишев Б. Реформа прокуратури: останній крок. 2014. URL: http://www.pravda.com.ua/ articles/2014/10/13/7040568/.

5. Стратегія розвитку органів внутрішніх справ. Олег Мартиненко, Свген Захаров. Реформування органів внутрішніх справ. 23.09.2014 року. URL: http://khpg.org/index.php?id=1411470323.

6. Кодекс етичної поведінки військових посадових осіб та інших осіб, уповноважених на виконання функцій держави, у Національній гвардії України від 03.05.2017. С. 1-4.

7. Закон України «Про національну безпеку України» від 21.06.2018 URL: https://zakon.rada.gov.ua/laws/show/2469-19.

8. Кодекс доброчесності співробітника Служби безпеки України, 2019. С. 9-32.

УДК 342.9

DOI https://doi.org/10.32844/2618-1258.2019.6.45

ЩУПАКІВСЬКИЙ Р.В.

\section{ПРО ПРАВОВУ РЕГЛАМЕНТАЦІЮ ДІЯЛЬНОСТІ ЗМІ ТА ЗАБЕЗПЕЧЕННЯ ПРАВА НА ІНФОРМАЦІЮ}

У статті розглядаються питання правового регулювання засобів масової інформації та права громадян на інформацію як засоби створення сприятливих умов для забезпечення інформаційного плюралізму. Інформаційний плюралізм визначається як кількість незалежних та автономних засобів масової інформації, які мають доступ до досить різноманітного спектру джерел інформації, засобів виробництва та розповсюдження засобів масової інформації, з одного боку, та показ засобами масової інформації різноманітних політичних, соціальних, релігійних та культурних поглядів із дотриманням редакційної незалежності та поваги до цих правил саморегулювання, з іншого. Удосконалюючи правове регулювання діяльності ЗМІ в Інтернеті, загалом доцільно застосовувати чинне законодавство про періодичні електронні засоби масової інформації до них, але необхідно запровадити оперативну процедуру реагування на порушення законодавства про інформацію в Інтернеті, зокрема поширення інформації, яка зачіпає честь і гідність людини, поширення інформації, яка зазіхає на суспільну мораль. Складність швидкого реагування на усунення таких порушень зумовлена, насамперед, глобальним характером цієї

() ЩУПАКІВСЬКИЙ Р.В. - кандидат юридичних наук, директор департаменту безпеки (Група компаній «Терра Фуд») 